\title{
How Firm Heterogeneity Affects OFDI Domestic Performance?
}

\author{
Xue Wang, Liyan Liu* \\ School of Economics and Management, Beijing Institute of Petrochemical Technology, Beijing, China \\ Email: *lucyliuliyan@bipt.edu.cn
}

How to cite this paper: Wang, X., \& Liu, L. Y. (2021). How Firm Heterogeneity Affects OFDI Domestic Performance? Journal of Service Science and Management, 14, 281-290.

https://doi.org/10.4236/jssm.2021.143017

Received: June 10, 2020

Accepted: May 31, 2021

Published: June 3, 2021

Copyright $\odot 2021$ by author(s) and Scientific Research Publishing Inc. This work is licensed under the Creative Commons Attribution International License (CC BY 4.0).

http://creativecommons.org/licenses/by/4.0/

(c) (i) Open Access

\begin{abstract}
This study was set out to identify the linkage between firm heterogeneity and domestic performance. Chinese firm level data from OFDI firms in manufacturing industry are applied from year 2011 to year 2013, factors as assets level, employment scale, market sales, profit level, salary level, import and export, destinated countries OFDI, sectors of investment are investigated with fixed effect panel data model. Output is used to signify firm's performance, and the sum of firm's import and export are applied to signify firms' international connection. Findings show that market sales and salary level presented a significant positive impact on the firms' output, while number of employees, profit level and international connections presented a negative effect on the growth of output. The assets and exporting status presented an unclear effect. The growth of output is also affected by the destinated country of OFDI and the sectors invested.
\end{abstract}

\section{Keywords}

Firm Heterogeneity, OFDI, Domestic Performance

\section{Introduction}

With the deepening of economic globalization, China's OFDI (outward foreign direct investment) continues to grow, and Chinese OFDI market is increasingly mature. As the second largest country in the global market of foreign investment, OFDI has become one of the important driving forces for China's domestic economic development. With the further development of the "going out" strategy, the performance of OFDI firms has become the core issue of China's foreign investment.

Due to the different individual characteristics of foreign investment firms, the ${ }^{\star}$ Corresponding author: Liyan Liu. 
performance of investment firms is significantly varied. Existing research mainly focuses on the performance of foreign investment at the national or provincial level, or the performance of a certain type of firm's foreign investment based on macro data. Few studies are focused on the performance of OFDI at the firm level. The existing research mainly involves research of the impact of the international environment and external policies on the performance of companies' foreign investment, and few considerations are given to the heterogeneity of the firms. And most of the policy recommendations put forward are more suitable for developed countries.

Based on the "List of Overseas Investment Enterprises (Institutions)", "the Chinese Industrial Enterprise Database", and "the China Customs Database", the study is set out to explore how heterogeneity affects OFDI firms' domestic performance. Based on corporate-level data of China's manufacturing firms which has invested and has import and export activities in countries along the "maritime silk road". The performance of OFDI firms is analyzed from the perspective of heterogeneity.

\section{Literature Review}

Regarding the study of foreign direct investment of firms, in the early stage the representative theory is Dunning's Ownership-Location-internalization (OLI) (Dunning, 1981), which believes that the advantages of enterprise ownership, internalization and location advantages are important factors affecting foreign investment decisions. The theory comprehensively analyzes and explains the determinants of international production, the form of international production, and the development degree of international production. Regarding the study of firms' foreign direct investment, the theory believes that the advantages of firms' ownership, internalization and location advantages are important factors affecting the decision-making of foreign investment.

On this basis, scholars incorporated various macro-factors of the home country and host country into the location selection model and discussed the influence of factors (Buckley et al., 2007) such as geographic distance, institutional distance, market conditions, resource endowments, and industry differences; (Kolstad \& Wiig, 2012; Ramasamy et al., 2012). With the development of heterogeneity theory and empirical research, Chinese economists have gradually begun to pay attention to the trade behavior of micro-enterprises (Cheng \& Ruan, 2004). However, due to the poor availability of corporate microdata, the focus of research is mostly at the level of factor endowment and policy analysis (Liming et al., 2017). The early research on heterogeneous corporate trade theory by Chinese scholars mainly focused on comprehensive research and learning (Wang \& Xu, 2017).

Macro-level research is mainly on the study of local policies, market differences, and labor differences based on actual local conditions and in-depth study of location factors (Jiang \& Jiang 2012; Sun \& Ding et al., 2019). In addition to 
the macro factors, scholars further linked the heterogeneity of firms with foreign direct investment decision-making. From the differences of firms at the micro level, they proposed the self-selection effect model of enterprise behavior (Helpman-Melitz-Yeaple, HMY) (Helpman et al., 2004), which verified the impact mechanism of productivity on corporate foreign investment (Bernard \& Jensen 2007; Yeaple et al., 2009).

With the in-depth research on firm's heterogeneity, more and more scholars believe that productivity cannot fully represent the differences between enterprises (Conconi et al., 2016). Scholars have begun to explain the impact of enterprise heterogeneity on enterprises in terms of innovation capabilities, export conditions, financing constraints, and ownership (Huang et al., 2017; Yan et al., 2018).

Based on this, the OFDI firm data of China's manufacturing industry are used to explore the impact of firm heterogeneity on enterprise performance from the perspective of firm heterogeneity, sector of investment, destinated country of investment and other multi-factor perspectives, to provide a certain reference for OFDI firms in developing countries.

\section{Model Specification and Data Description}

According to the Cobb-Douglas production function, capital input and labor input are important factors affecting firms' performance. At the same time, the level of firms' market development, firms' profitability, employee income levels, the sectors in which the firm is located, the country of investment destination, firms' international connections, and whether it is exporting may all affect firms' performance. Considering a variety of factors, the following Econometric model is set as follows,

$$
\begin{aligned}
\text { LNOUTPUT }_{i t}= & \beta_{0}+\beta_{1} \text { LNASSET }_{i t}+\beta_{2} \text { LNEMP }_{i t}+\beta_{4} \text { LNSALE }_{i t} \\
& +\beta_{7} \text { LNPROFIT }_{i t}+\beta_{8} \text { LNSAL }_{i t}+\beta_{9} \text { SECTOR }_{i t} \\
& +\beta_{10} \text { CONTRY }_{i t}+\beta_{11} \text { LNINTER }_{i t}+\beta_{12} \text { EX }_{i t}+\epsilon_{i t}
\end{aligned}
$$

Here the subscript $i$ represents the foreign investment enterprise, $t$ represents the year; $\epsilon_{i t}$ it is the error term.

${ }_{O U T P U T}$ it is the firm's output in the current year, representing firms' performance; $A_{S S E T_{i t}}$ represents the company's total assets; $E M P_{i t}$ represents labor inputs; $S A L E_{i t}$ is the market sales, which represents firms' market development level; $P R O F I T_{i t}$ is the firm's current year's profit, representing the level of firms' profitability; $S A L_{i t}$ is the current year's employee wages, representing the employee's income level; SECTOR $R_{i t}$ is the sector in which firm invested; COUNTRY it is the destination country of the firm's OFDI; INTER is the firm's degree of openness, or the level of international relevance, measured by the logarithm of the company's total import and export volume; EX is whether the company has exports or not.

344 firms are selected that have made direct investments and have import and export trade in countries along the "Maritime Silk Road" from year 2011 to year 
2013. ${ }^{1}$ All data comes from the "List of Overseas Investment Enterprises (Institutions)", "the Chinese Industrial Enterprise Database", and "the China Customs Database”. Capital inputs, labor inputs, firms' market development, profitability, employee income, international connections, and so on are all de-inflated based on the price level of year 2010.

After de-inflation, the original data is logarithmically processed according to Equation (1) and the following characteristics are shown. According to the following mean value, standard deviation, maximum and minimum value of the overall data in Table 1, the dataset is balanced panel data with small standard deviations and no outliers.

\section{Empirical Analysis}

\subsection{Pooled Regression}

As a frame of reference, pooled regression was carried out first. We first assume that the regression equation of the firms are the same and individual specific effects are absent. Cluster robust standard error pooled regression, robust standard error pooled regression and standard error pooled regression were performed respectively. The results are shown in Table 2.

It can be seen from the results in Table 2 that the three types of errors have similar results. Factors of market sales and country of destination are significant in all three progression models, and all other factors are statistically insignificant.

In the pooled regression model, it is assumed that all firms have the same regression equation. Sample firms selected are all manufacturing firms and investing in countries along the "Maritime Silk Road", they may have remarkably similar regression equations, however, since each firm has its specific characteristics, that is, individual differences or heterogeneity.

Therefore, we need to use F-test to further confirm if there are individual specific effects. The $\mathrm{P}$ value of the $\mathrm{F}$ test is 0.0000 , which strongly rejects the null hypothesis. Therefore, each firm has its own invariant heterogeneity, that is, intercept term, and the mixed regression results are not effective.

\subsection{Fixed Effect Regression and Random Effect Model}

There are two kinds of kinds of individual-specific effects model involved, which are Fixed Effects Model $(\mathrm{FE})^{2}$ and Random Effect Model (RE). Therefore, we ${ }^{1}$ The "Belt and Road" is connected to the Pacific Ocean in the east, the Baltic Sea in the west, and runs through Asia, Europe and Africa, covering 65 countries in Central Asia, West Asia, North Africa, Southeast Asia, South Asia and Central and Eastern Europe, involving 11 ASEAN countries, 18 West Asia countries, 8 South Asia countries, and Central Asia. 5 countries, 7 CIS countries and 16 countries in Central and Eastern Europe. Among them, there are 25 countries along the "Maritime Silk Road "and 40 countries on the "land Silk Road". Here we selected 21 countries including Bangladesh, Brunei, Cambodia, Egypt, India, Indonesia, Iran, Kuwait, Laos, Malaysia, Myanmar, Pakistan, Philippines, Saudi Arabia, Singapore, Sri Lanka, Thailand, UAE, Vietnam, and Qatar as countries along "Maritime Silk Road".

2 The word "fixed effects" may be misunderstood. Even in fixed effects model, individual-specific effects - $-\mu$ i is still a random one, but not a fixed constant. 
perform both respectively. Fixed effect model regression is shown in Table 3. And the results of random effects model are presented in Table 4.

From the results of fixed effects model and random effects model, we can see that the results are significantly different. In the fixed effect model, all factors are statistically significant except the factors of assets and export. While in random effect model, only market sales and destination country of OFDI are significant.

Table 1. Statistical Summary of the data.

\begin{tabular}{|c|c|c|c|c|c|c|}
\hline Variable & & Mean & Std. Dev. & Min & $\operatorname{Max}$ & Observations \\
\hline \multirow[t]{3}{*}{ lnoutp } & overall & 12.7132 & 1.718333 & 9.61808 & 17.68503 & $\mathrm{~N}=344$ \\
\hline & between & & 1.707877 & 9.61808 & 17.68503 & $\mathrm{n}=331$ \\
\hline & within & & 0.058439 & 12.2398 & 13.18661 & T-bar $=1.03927$ \\
\hline \multirow[t]{3}{*}{ lnasset } & overall & 12.56505 & 2.030446 & 7.997322 & 17.53869 & $\mathrm{~N}=344$ \\
\hline & between & & 2.023572 & 7.997322 & 17.53869 & $\mathrm{n}=331$ \\
\hline & within & & 0.037845 & 12.1676 & 12.9625 & T-bar $=1.03927$ \\
\hline \multirow[t]{3}{*}{ lnemp } & overall & 6.342739 & 1.240679 & 3.526361 & 10.27946 & $\mathrm{~N}=344$ \\
\hline & between & & 1.225394 & 3.526361 & 10.27946 & $\mathrm{n}=331$ \\
\hline & within & & 0.032037 & 6.108399 & 6.577079 & T-bar $=1.03927$ \\
\hline \multirow[t]{3}{*}{ Insale } & overall & 12.68471 & 1.714141 & 9.61808 & 17.70685 & $\mathrm{~N}=344$ \\
\hline & between & & 1.70653 & 9.61808 & 17.70685 & $\mathrm{n}=331$ \\
\hline & within & & 0.043854 & 12.36319 & 13.00623 & T-bar $=1.03927$ \\
\hline \multirow[t]{3}{*}{ lnprofit } & overall & 8.182021 & 5.566073 & -13.2544 & 15.23455 & $\mathrm{~N}=344$ \\
\hline & between & & 5.360028 & -13.0953 & 15.23455 & $\mathrm{n}=331$ \\
\hline & within & & 1.155097 & -2.52625 & 18.89029 & T-bar $=1.03927$ \\
\hline \multirow[t]{3}{*}{ lnsal } & overall & 9.895905 & 1.72555 & 5.428046 & 15.75628 & $\mathrm{~N}=344$ \\
\hline & between & & 1.708076 & 5.428046 & 15.67765 & $\mathrm{n}=331$ \\
\hline & within & & 0.077623 & 8.970002 & 10.82181 & T-bar $=1.03927$ \\
\hline \multirow[t]{3}{*}{ sector } & overall & 29.34012 & 8.985444 & 6 & 44 & $\mathrm{~N}=344$ \\
\hline & between & & 8.998848 & 6 & 44 & $\mathrm{n}=331$ \\
\hline & within & & 0.07636 & 28.84012 & 29.84012 & T-bar $=1.03927$ \\
\hline \multirow[t]{3}{*}{ country } & overall & 10.625 & 5.603161 & 1 & 19 & $\mathrm{~N}=344$ \\
\hline & between & & 5.529478 & 1 & 19 & $\mathrm{n}=331$ \\
\hline & within & & 1.15428 & 3.125 & 18.125 & T-bar $=1.03927$ \\
\hline \multirow[t]{3}{*}{ lninter } & overall & 23.61943 & 8.333098 & 0 & 40.75674 & $\mathrm{~N}=345$ \\
\hline & between & & 8.33294 & 0 & 40.75674 & $\mathrm{n}=332$ \\
\hline & within & & 0.629708 & 17.43863 & 29.80024 & $\mathrm{~T}$-bar $=1.03916$ \\
\hline \multirow[t]{3}{*}{ ex } & overall & 0.575581 & 0.494974 & 0 & 1 & $\mathrm{~N}=344$ \\
\hline & between & & 0.491077 & 0 & 1 & $\mathrm{n}=331$ \\
\hline & within & & 0.093522 & 0.075581 & 1.075581 & T-bar $=1.03927$ \\
\hline
\end{tabular}


Table 2. Comparison of three pooled regression.

\begin{tabular}{cccccccccc}
\hline \multirow{2}{*}{ lnoutp } & \multicolumn{2}{c}{ Cluster-Robust standard error } & \multicolumn{2}{c}{ Robust standard error } & \multicolumn{3}{c}{ Standard error } \\
\cline { 2 - 9 } & Coef. & Std. Err. & $\mathbf{P}>|\mathbf{t}|$ & Coef. & Std. Err. & $\mathbf{P}>|\mathbf{t}|$ & Coef. & Std. Err. & $\mathbf{P}>|\mathbf{t}|$ \\
\hline Inasset & 0.000462 & 0.0064033 & 0.943 & 0.000462 & 0.0063749 & 0.942 & 0.000462 & 0.0069606 & 0.947 \\
lnemp & -0.0094815 & 0.0106149 & 0.372 & -0.0094815 & 0.0104395 & 0.364 & -0.0094815 & 0.0073436 & 0.198 \\
lnsale & 1.001695 & 0.0086144 & 0.000 & 1.001695 & 0.0083712 & 0.000 & 1.001695 & 0.0087208 & 0.000 \\
lnprofit & 0.0001548 & 0.0007684 & 0.840 & 0.0001548 & 0.0007583 & 0.838 & 0.0001548 & 0.0010297 & 0.881 \\
Insal & 0.0033551 & 0.007644 & 0.661 & 0.0033551 & 0.0074641 & 0.653 & 0.0033551 & 0.0074873 & 0.654 \\
sector & 0.000587 & 0.0004633 & 0.206 & 0.000587 & 0.0004492 & 0.192 & 0.000587 & 0.0006298 & 0.352 \\
country & 0.0019612 & 0.0010303 & 0.058 & 0.0019612 & 0.001156 & 0.091 & 0.0019612 & 0.000985 & 0.047 \\
lninter & 0.0006741 & 0.0006933 & 0.332 & 0.0006741 & 0.0006781 & 0.321 & 0.0006741 & 0.0007971 & 0.398 \\
ex & 0.0037165 & 0.0111339 & 0.739 & 0.0037165 & 0.010566 & 0.725 & 0.0037165 & 0.0108544 & 0.732 \\
cons & -0.0293093 & 0.0570048 & 0.607 & -0.0293093 & 0.0548073 & 0.593 & -0.0293093 & 0.0477682 & 0.540 \\
\hline
\end{tabular}

Table 3. Fixed effect model.

\begin{tabular}{ccccccc}
\hline lnOUTP & Coef. & Std. Err. & $\mathbf{t}$ & $\mathbf{P}>|\mathbf{t}|$ & [95\% Conf. & Interval] \\
\hline lnasset & 0.0417723 & 0.1737819 & 0.24 & 0.810 & -0.3000877 & 0.3836322 \\
lnemp & -1.961882 & 0.3109876 & -6.31 & 0.000 & -2.57365 & -1.350113 \\
Insale & 1.637151 & 0.2133924 & 7.67 & 0.000 & 1.21737 & 2.056932 \\
lnprofit & -0.0368069 & 0.0087044 & -4.23 & 0.000 & -0.0539299 & -0.0196838 \\
lnsal & 1.001138 & 0.1810688 & 5.53 & 0.000 & 0.6449431 & 1.357333 \\
sector & 0.6286804 & 0.1591778 & 3.95 & 0.000 & 0.3155493 & 0.9418116 \\
country & 0.0405621 & 0.0074041 & 5.48 & 0.000 & 0.0259971 & 0.0551272 \\
lninter & -0.0324923 & 0.0099708 & -3.26 & 0.001 & -0.0521067 & -0.0128779 \\
ex & -0.0677961 & 0.0621712 & -1.09 & 0.276 & -0.190098 & 0.0545058 \\
_cons & -23.80859 & 6.158515 & -3.87 & 0.000 & -35.92349 & -11.69369 \\
sigma_u & 5.9932677 & & & & & \\
sigma_e & 0.11160688 & & & & & \\
rho & 0.99965334 (fraction of variance due to u_i) & & & \\
\hline
\end{tabular}

Table 4. Random effect model.

\begin{tabular}{|c|c|c|c|c|c|c|}
\hline $\operatorname{lnOUTP}$ & Coef. & Std. Err. & $\mathrm{t}$ & $P>|t|$ & [95\% Conf. & Interval] \\
\hline lnasset & 0.000462 & 0.0064033 & 0.070 & 0.942 & -0.0120883 & 0.0130122 \\
\hline lnsale & 1.001695 & 0.0086144 & 116.28 & 0.000 & 0.9848112 & 1.018579 \\
\hline lnprofit & 0.0001548 & 0.0007684 & 0.200 & 0.840 & -0.0013513 & 0.0016608 \\
\hline lnsal & 0.0033551 & 0.007644 & 0.440 & 0.661 & -0.0116269 & 0.018337 \\
\hline sector & 0.000587 & 0.0004633 & 1.270 & 0.205 & -0.0003211 & 0.0014951 \\
\hline country & 0.0019612 & 0.0010303 & 1.900 & 0.057 & -0.0000581 & 0.0039805 \\
\hline
\end{tabular}




\begin{tabular}{|c|c|c|c|c|c|c|}
\hline lninter & 0.0006741 & 0.0006933 & 0.970 & 0.331 & -0.0006848 & 0.002033 \\
\hline ex & 0.0037165 & 0.0111339 & 0.330 & 0.739 & -0.0181056 & 0.0255386 \\
\hline _cons & -0.0293093 & 0.0570048 & -0.510 & 0.607 & -0.1410367 & 0.082418 \\
\hline sigma_u & 0 & & & & & \\
\hline sigma_e & .11160688 & & & & & \\
\hline rho & \multicolumn{6}{|c|}{0 (fraction of variance due to $\left.\mathrm{u} \_\mathrm{i}\right)$} \\
\hline
\end{tabular}

Table 5. Hausman test (fixed effects and random effects.

\begin{tabular}{ccccc}
\hline & \multicolumn{3}{c}{ coefficients } \\
\cline { 2 - 5 } & (b) FE & (B) RE & (b-B) Difference & sqrt(diag(V_b-V_B) ) S.E. \\
\hline lnasset & 0.0417723 & 0.000462 & 0.0413103 & 0.3475335 \\
lnemp & -1.961882 & -0.0094815 & -1.9524 & 0.5618493 \\
lnsale & 1.637151 & 1.001695 & 0.635456 & 0.3739597 \\
lnprofit & -0.0368069 & 0.0001548 & -0.0369617 & 0.0130951 \\
Insal & 1.001138 & 0.0033551 & 0.9977828 & 0.3295843 \\
sector & 0.6286804 & 0.000587 & 0.6280935 & 0.235726 \\
country & 0.0405621 & 0.0019612 & 0.038601 & 0.0103643 \\
lninter & -0.0324923 & 0.0006741 & -0.0331664 & 0.0148397 \\
ex & -0.0677961 & 0.0037165 & -0.0715126 & 0.0820911 \\
_cons & -23.80859 & -0.0293093 & -23.77928 & 8.393102 \\
\hline
\end{tabular}

$\mathrm{b}=$ consistent under Ho and Ha; obtained from xtreg. $\mathrm{B}=$ inconsistent under Ha, efficient under Ho; obtained from xtreg. Test: Ho: difference in coefficients not systematic. chi2 $(9)=$ $(\mathrm{b}-\mathrm{B})^{\prime}\left[\left(\mathrm{V} \_\mathrm{b}-\mathrm{V} \_\mathrm{B}\right)^{\wedge}(-1)\right](\mathrm{b}-\mathrm{B})=28.83$. Prob $>\mathrm{chi}^{2}=0.0007$.

\subsection{Further Test of the Results}

$\mathrm{T}$ further investigate the validity and scientificity of the above two model estimation results, Hausman Test is carried out on the fixed effect model and random effect model respectively to determine the scientificity of the above results (see Table 5).

Test results in Table 5 show that $\mathrm{P}$ value equals 0.0007 , which strongly reject the H0 hypothesis, which indicates that the difference in coefficients is systematic, and fixed effects regression is effective.

\section{Discussion}

From the results of fixed effect model (Table 3), except assets level and exporting status, all factors are statistically significant on the level of $1 \%$. Market sales, salary level, destinated country and sector of OFDI have positive impacts on the output of OFDI firms. While employment level, profit level international connections have significantly negative impacts on firms' output level.

The coefficient of market sales is 1.6371 , indicating that market sales increased 
by $1 \%$, output increased by $1.6371 \%$, and market sales had a multiplier effect on output growth. Wage level has a significant positive effect on output, with a coefficient of 1.0011, indicating that an increase in work level will increase employee morale and working status, and help increase output. In addition, high wages correspond to employees with stronger technical and innovative capabilities. Improving employees' technical and innovative capabilities has a positive effect on output growth. Both the investment destination country and the investment sectors have a significant effect on output, indicating that OFDI companies must carefully select the investment country and investment sectors. Profit level and international connections has a significant negative impact on firms' outputs, indicating that pursuit of profits will hinder the growth of outputs, and the import or export of intermediate goods will reduce domestic production.

The number of employees, the level of profit, and the volume of imports and exports have a significant negative effect on output. The coefficient of employment is -1.9618 , indicating that the increase in employment has a significant inhibitory effect on output growth, indicating that labor input has reached saturation, and labor input can no longer be used to increase output. Capital has no significant effect on the growth of output, indicating that manufacturing companies should devote themselves to technological advancement and technological innovation, and improve output levels through innovation. The level of profit and the volume of imports and exports have a restraining effect on output growth, indicating that expanding profits and increasing imports and exports cannot promote the increase in output.

\section{Conclusion}

Based on the data of OFDI firms with import and export activities in manufacturing industry, we established the panel data model to explore how firm heterogeneity affects their outputs. Factors as assets level, employment level, market sales, market profits, employee salaries, international connection, exporting status, destinated country of OFDI and sectors of investment are invested. The study offered a firm level study and provided a reference for the output analysis in developing countries. However, since the samples are focused on the manufacturing firms, therefore, it excludes OFDI firms in the service industry, which is the limitation for the study.

Findings show that assets and exporting status do not show significant impacts on the outputs of OFDI firms during the study period. Market sales, salary level of employees, sectors invested, and country of destination have positive impacts on firms' outputs, while employee scale, market profit and international connections present negative effects in the study period.

It should be noted that assets show no positive impacts on firms' output, and employee scale has negative impacts on firms' output. This is contrary to the conclusions obtained from the analysis of most production function growth fac- 
tors. This shows that the output growth of OFDI firms in manufacturing industry could not be further promoted by capital and labor inputs. The promotion of outputs should be enhanced by technology innovation. Therefore, firms should focus more on technology upgrading and innovation, to further improve productivity hence increase outs.

Employees' salary level is closely related to employees' technology efficiency and professional skills. The increase of employees' salary presented a significantly positive impact on outputs, indicating that more professional and efficient labor would be beneficial for the growth of outputs. Therefore, efforts should be taken to improve employees' professional knowledge and skills from the recruiting to employee training, such as cooperation with famous universities to codevelop talents, performance-related promoted programs to improve employees' professional skills, and talents training should be an important target for firms' human resource development.

\section{Supporting Projects}

OFDI's performance from the perspective of firm heterogeneity, Beijing URT Project (2020J00064).

\section{Conflicts of Interest}

The authors declare no conflicts of interest regarding the publication of this paper.

\section{References}

Bernard, A. B., \& Jensen, J. B. (2007). Firm Structure, Multinationals, and Manufacturing Plant Deaths. Review of Economic and Statistic, 89, 193-204. https://doi.org/10.1162/rest.89.2.193

Buckley, P. J., Clegg, J., \& Wang, C. Q. (2007). Is the Relationship between Inward FDI and Spillover Effects Linear? An Empirical Examination of the Case of China. Journal of International Business Studies, 38, 447-459. https://doi.org/10.1057/palgrave.jibs.8400274

Cheng, H. F., \& Ruan, X. (2004). The Location Choice of China's Foreign Direct Investment Analysis with Gravity Model. World Economy, No. 11, 23-30.

Conconi, P., Sapir, A., \& Zanardi, M. (2016). The Internationalization Process of Firms: From Exports to FDI. Journal of International Economics, 99, 16-30.

https://doi.org/10.1016/j.jinteco.2015.12.004

Dunning, J. (1981). International Production and Multinational Enterprises. London: Allen and Unwin.

Helpman, E., Melitz, M., Yeaple, S. R. (2004). Export versus FDI with Heterogeneous Firms. America Economic Review, 94, 300-316. https://doi.org/10.1257/000282804322970814

Huang, Y. Y., Xie, E., Li, Y. et al. (2017). Does State Ownership Facilitate outward FDI of Chinese SOEs? Institutional Development, Market Competition, and the Logic of Interdependence between Governments and SOEs. International Business Review, 26, 176-188. https://doi.org/10.1016/j.ibusrev.2016.06.005 
Jiang, G. H., \& Jiang, D. C. (2012). The Location Choice of China's Foreign Investment: A Panel Data Test Based on the Investment Gravity Model. The World Economy, No. 9, 21-40.

Kolstad, I., \& Wiig, A. (2012). What Determines Chinese Outward FDI? Journal of World Business, 47, 26-34. https://doi.org/10.1016/j.jwb.2010.10.017

Li, M., Xia, X. M., Zhu, S. J. et al. (2017). The Temporal and Spatial Evolution of China's Direct Investment in Africa and Its Influencing Factors. Economic Geography, 37, 19-27.

Ramasamy, B., Yeung, M., \& Laforet, S. (2012). China's Outward Foreign Direct Investment: Location Choice and Firm Ownership. Journal of World Business, 47, 17-25. https://doi.org/10.1016/j.jwb.2010.10.016

Sun, J. S., \& Ding, N. (2019). Enterprise Heterogeneity, Labor Heterogeneity and Skill Wage Gap. Business Economics and Management, No. 8, 41-57.

Wang, M. J., \& Xu, Y. P. (2017). The Basic Characteristics and Determinants of China's OFDI in American. Acta Geographica Sinica, 72, 1373-1391.

Yan, B., Zhang, Y., Shen, Y. Z. et al. (2018). Productivity, Financial Constraints and Outward Foreign Direct Investment: Firm Level Evidence. China Economic Review, 47, 47-64. https://doi.org/10.1016/j.chieco.2017.12.006

Yeaple, S. R. (2009). Firm Heterogeneity and the Structure of US Multinational Activity. Journal of International Economics, 78, 206-215.

https://doi.org/10.1016/j.jinteco.2009.03.002 